\title{
AFLP Primer Selection for the Analysis of Genetic Diversity in Persimmon (Diospyros kaki L.) Originated From Central and East Java, Indonesia
}

\author{
Marshelina Noor Indah Delfianti ${ }^{1}$, Endang Yuniastuti ${ }^{2, *}$ and Vita Ratri Cahyani ${ }^{2}$ \\ ${ }^{1}$ Master Program of Agronomy, Graduate Program, University of Sebelas Maret, St. Sutami 36A Kentingan Surakarta Central Java 57126, \\ Indonesia $;^{2}$ Department of Agrotechnology, Faculty of Agriculture, University of Sebelas Maret, St. Sutami 36A Kentingan Surakarta \\ Central Java 57126, Indonesia
}

Received: March 17, 2020; Revised: September 13, 2020; Accepted: September 19, 2020

\begin{abstract}
Persimmon (Diospyros kaki L.) belongs to the family Ebenaceae known as the Japanese persimmon kaki. This crop was introduced in the Highlands in Central and East Java-Indonesia. A genetic analysis of a small sample of accessions was conducted using the Amplified Fragment Length Polymorphism (AFLP) method with IRDye700 labelled Pst1 (P11-700) and Mse 1 restriction enzymes and seven primers combinations (M48, M49, M50, M51, M53, M55, and M58). The analysis resulted in a set of 441 bands, of which 117 were monomorphic and 324 polymorphic. The average percentage of polymorphic bands was $73.4 \%$. The four persimmon accessions were genetically distinguished into three groups, with a high genetic diversity among them, while accessions B (Batu) and D (Dampit) show little differences in their profiles.
\end{abstract}

Keywords: Diospyros kaki L., AFLP markers, Pst1, Mse1, genetic diversity.

\section{Introduction}

Persimmon (Diospyros kaki L.) belongs to the family of Ebenaceae and is known as Japanese foot Persimmon. This plant is native to Central China and has been introduced in Korea, Japan as well as other subtropical countries (Ikegami et al., 2009). In the early $20^{\text {th }}$ century, this crop began to enter Southeast Asia including Indonesia (Java and Sumatra), Malaysia and Thailand (Butt et al., 2015).

In Indonesia, this plant is widely grown in highlands such as Selo-Boyolali (Delfianti et al., 2019), Magetan (Wardani et al., 2019b), Junggo-Batu (Baswarsiati et al., 2006), Dampit-Malang, Garut; Majalengka (Setiawan, 2017), Brastagi; Karo-Sumatera Utara (Hanafiah et al., 2018). Persimmon can grow well at an altitude of 1,000 $1,500 \mathrm{~m}$ above sea level according to Delfianti et al., (2019) where plants require a mild and humid climate for survival.

Persimmon is classified in astringent and non astringent types. According to Butt et al., (2015); Drahansky et al., (2016); Min et al., (2012) astringent persimmon tastes bitter. It is a fruit intended for cooking and requires to overripe to have the astringency removed, while the non astringent persimmon can be eaten immediately after the harvest and does not require to overripe. Persimmon cultivated in Indonesia is an astringent type and is harvested by farmers although they prefer to grow more profitable horticultural crops such as vegetables and citrus. Accordings to Delfianti et al., (2019) and Ridwan \& Iskandar Ishaq (2005) in Indonesia persimmon is propagated by rooted cuttings although the percentage of plants obtained is relatively small. To increase the interest of farmers in cultivating persimmons breedingprograms might be developed to produce new varieties of good quality and quantity.

There are two basic methods to study the genetic diversity: the phenotypic and the genotypic ones. According to Hanafiah et al. (2018), the phenotypic method uses morphological characters, but is often influenced by environmental factors so that differences between genotypes are difficult to analyze especially if they do not have a simple genetic control system. The genotypic methods are supported by molecular analysis (Syam et al., 2012).

According to Jones et al. (1997), there are several kinds of DNA markers, namely Random Amplified Polymorphic DNA (RAPD), Restriction Fragment Length Polymorphism (RFLP), Amplified Fragment Length Polymorphism (AFLP), Simple Sequence Repeat (SSR) or DNA microsatellites.

Amplified Fragment Length Polymorphism (AFLP) is a study technique of genetic diversity based on DNA fragments obtained by restriction enzymes and selective amplification of these fragments (Makful et al., 2010; Vos et al., 1995). The basic principle of AFLP technique is to detect the difference in fragment length polymorphism among compared samples (Saunders et al., 2001).

\footnotetext{
* Corresponding author. e-mail: : yuniastutisibuea@staff.uns.ac.id.
} 


\section{Materials and Methods}

\subsection{Sample collection}

Persimmon (D. kaki L.) leaves were collected from a single tree in the following locations:

- Central Java Province, which consisted of two villages: Jrakah (coded J), located at $07^{\circ} 29^{\prime} 05.641 " S$ - $110^{\circ} 25^{\prime}$ 27.815"E dan 1,400 m above sea level and Gebyok (coded G), located at 7²9’57.4”'S - 110²8'16.1'E dan 1,499 m above sea level

- East Java Province, which consisted of two villages: Batu (coded B), located at 0780'18.370"S $112^{\circ} 52^{\prime}$ '47.787’'E dan 1,318 m above sea level and Dampit (D), located at $08^{\circ} 14^{\prime} 92.001$ 'S -

$112^{\circ} 85^{\prime} 90.381$ ”'E dan 1,130 m above sea level

The distance between the two villages in Central Java province is $6.8 \mathrm{~km}$ from each other. The distance between villages of East Java province is $53.4 \mathrm{~km}$.

\subsection{DNA Isolation and quantification}

DNA of leaves taken from the field was isolated using a genomic DNA Mini Kit (Plant) following the manufacturer's instructions.

DNA was quantifyed using a spectrophotometry and concentration, and purity of DNA at $\lambda 260 \mathrm{~nm}$ and $\lambda 280 \mathrm{~nm}$ (Sambrook et al., 1989; Witkowski, 1995) was recorded.

\subsection{AFLP Analysis}

AFLP analysis used the method of Vos et al., (1995) modified on primer labeling with IRD 700 . The steps were:

Restriction and ligation: The DNA was treated with the Pst1 and Mse 1 restriction enzymes (Suryati et al., 2013). The reaction mixture included $5 \mu 1$ of DNA (100 $\mathrm{ng} / \mu \mathrm{l}) ; 0.25 \mu \mathrm{l}$ restriction enzymes Pst 1 and $M s e 1 ; 0.5 \mu \mathrm{l}$ Pst1 adapter and Mse 1 adapter; $0.5 \mu \mathrm{l}$ ATP $10 \mathrm{mM} ; 2.5 \mu \mathrm{l}$

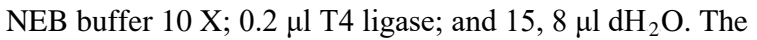
mixture was incubated for 24 hours at $37^{\circ} \mathrm{C}$.

Pre-amplification: Pre-amplification process required $10 \mu \mathrm{l}$ of RL plus $1.2 \mu \mathrm{l}$ primer Pst1 (P00), 1.2 primer $\mu 1$ Mse1 (Mo2), $0.8 \mu \mathrm{l} 10 \mathrm{mM}$ dNtp, 0.4 Taq Polimerase 5 $\mathrm{U} / \mu \mathrm{l}$. Pre-Amplification was carried out with the following PCR profile: denaturation at $94{ }^{\circ} \mathrm{C}$ for $30 \mathrm{sec}$, $56{ }^{\circ} \mathrm{C}$ for 30 seconds and extension of $72{ }^{\circ} \mathrm{C}$ for 60 seconds for 24 cycles. Pre-amplification product was diluted $10 \mathrm{x}$ and $10 \mu \mathrm{l}$ as a DNA template was used for further selective amplifications. AFLP primer for the preamplification were Pst1 (5' GACTGCGTACATGCAG3') and Mse 1 (5'GATGAGTCCTGAGTAAC3').

Selective Amplification: Selective amplification used seven primer combinations (Muluvi et al., 1999), the Pst1 primer 5' GACTGCGTACATGCAGAA3' was labeled with I IRDye 700 (P11-700) ; while Mse1 primer sequences are reported in Table 2.
Fragment separation and visualization: The electrophoresis of the products of selective amplification was carried out using the LI-COR 4300 DNA analyzer equipment and the acrylamide gel at $6.5 \%$. The gel for electrophoresis was made by mixing $20 \mathrm{ml}$ of $\mathrm{KB}$ plus $6.5 \%$ gel matrix; $12.5 \mu 1$ Tetramethilenediamine (TEMED) and $150 \mu \mathrm{l}$ ammonium Persulfat (APS) $10 \%(\mathrm{~b} / \mathrm{V})$. The mixture was then inserted into the glass plates and allowed to solidify. The gel was run with the TBE buffer $1 \mathrm{X}$. Preelectrophoresis was performed for 20 minutes with 20 watt to raise the temperature up to $50^{\circ} \mathrm{C}$. As much as $10 \mu$ of DNA sample, coupled with $10 \mu \mathrm{l}$ of loading buffer, formamid 98\% (b/V), EDTA $10 \mathrm{mM}$, blue bromophenol $0.1 \%(\mathrm{~b} / \mathrm{V})$ with the same volume $(10 \mu \mathrm{l})$ so that the mixture becomes $20 \mu \mathrm{l}$. All the samples were denatured at $94{ }^{\circ} \mathrm{C}$ for 10 minutes and then moved into the ice for approx. 5 minutes. The electrophoresis was run for a. 3 hours with 40 watt and 1500 voltage.

\subsection{Data Analysis.}

The DNA bands were scored and converted into binary data ( $1=$ presence, $0=$ absence). The differences between samples were analysed using a similarity matrix from which a UPGMA (unweighted pair group method with arithmetic mean) dendrogram was constructed (Rohlf 1988).

\section{Result and Discussion}

\subsection{DNA Isolation and Quantity and QualityTest}

Data on concentration and purity of persimmon DNA are reported in Table 1.

Table 1. Result of Persimmon DNA Quantification

\begin{tabular}{clll}
\hline No. & Sample & Concentration $(\mathrm{ng} / \mu \mathrm{l})$ & $\lambda 260 / 280$ \\
\hline 1. & Jrakah & 80.5 & 1.94 \\
2. & Gebyok & 85.2 & 1.91 \\
3. & Batu & 90.3 & 1.95 \\
4. & Dampit & 82.4 & 1.97 \\
\hline
\end{tabular}

DNA quality of the four samples of persimmon ranged between 1.91 and 1.97. According to Sambrook et al., (1989); Sundari (2018); Wardani et al., (2019) the absorbancy ratio of a DNA of good quality ranges from 1.8 to 2.0 .

The DNA concentration was in the range of 80.5 $90.3 \mathrm{ng} / \mu \mathrm{l}$.

\subsection{The AFLP analysis}

The study used 7 primer combinations, including P11M48; P11-M49; P11-M50; P11-M51; P11-M53; P11-M55; and P11-M58. The primers combination produced the number of bands reported in table 2 . 
Table 2. Primers combinations and number of AFLP bands produced in four persimmon accessions

\begin{tabular}{|c|c|c|c|c|c|}
\hline No. & Primer & Sequence (5’-3’) & Amplicons (n) & Polymorphic bands (n) & Polymorphism (\%) \\
\hline 1. & P11-M48 & GATGAGTCCTGAGTAACAC & 64 & 49 & 76 \\
\hline 2. & P11-M49 & GATGAGTCCTGAGTAACAG & 50 & 35 & 70 \\
\hline 3. & P11-M50 & GATGAGTCCTGAGTAACAT & 55 & 43 & 78 \\
\hline 4. & P11-M51 & GATGAGTCCTGAGTAACCA & 73 & 51 & 69 \\
\hline 5. & P11-M53 & GATGAGTCCTGAGTAACCG & 45 & 19 & 42 \\
\hline 6. & P11-M55 & GATGAGTCCTGAGTAACGA & 84 & 70 & 83 \\
\hline 7. & P11-M58 & GATGAGTCCTGAGTAACGT & 70 & 57 & 81 \\
\hline \multicolumn{3}{|c|}{ Total or average } & 441 & 324 & 73.4 \\
\hline
\end{tabular}

The amount of bands obtained from the seven primer combinations and four samples were as many as 441 . The largest number of bands was produced by the P11-M55 primers pair with as much as 84 bands, while the lowest number of bands was produced by the primers pair P11M53 with only 45 bands.

The size of the AFLP bands obtained ranged from 50 to 700 bp (Figure 1).
Based on the pattern of the AFLP bands, it can be concluded that there is polymorphism on the four persimmon samples in the seven primer combinations used. Of the total of 441 bands, 117 were monomorphic and present in all samples and 324 were polymorphic. The polymorphic bands ranged from 42 to $83 \%$ according to the primers combination.

The sample clustering produced the dendrogram of Figure

\section{2.}

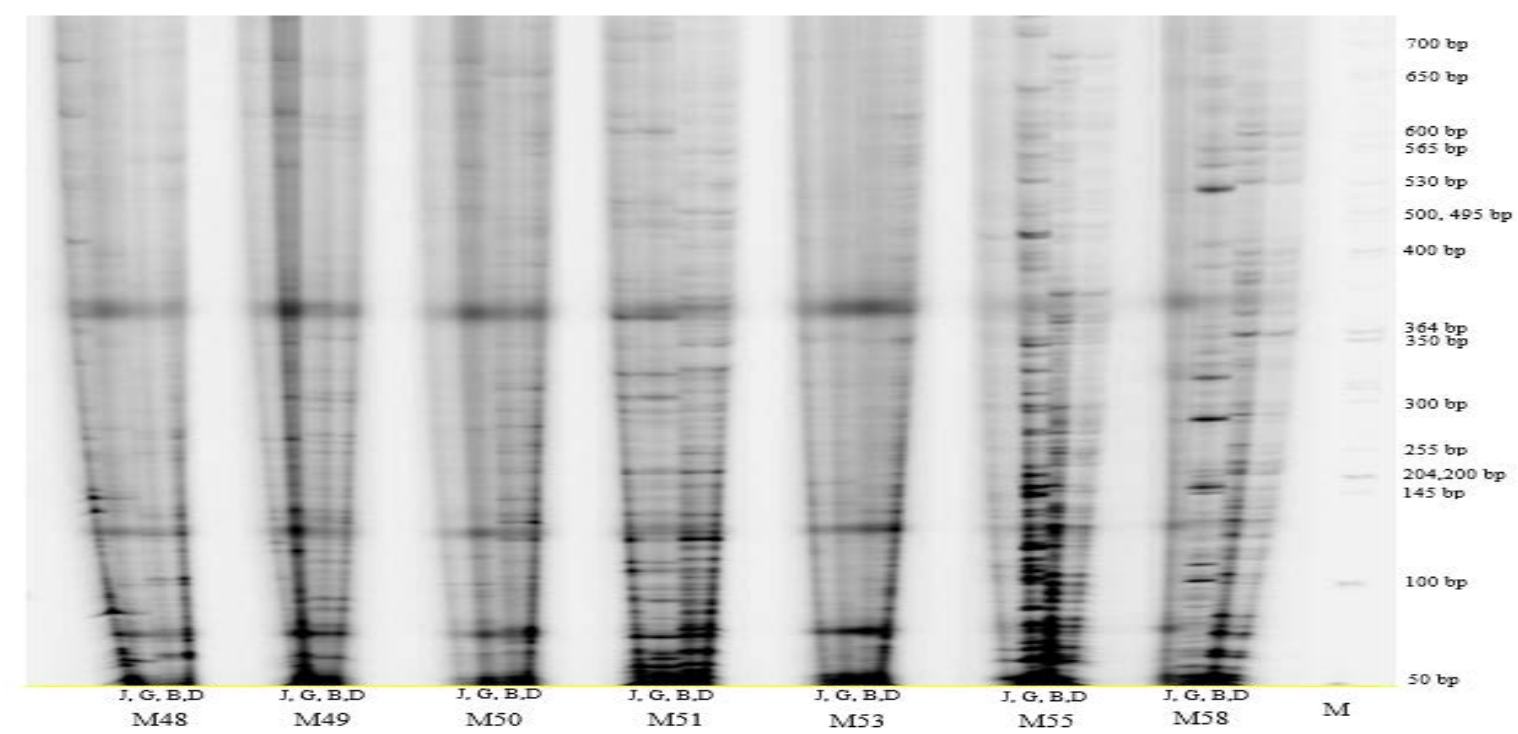

Figure 1. AFLP fragment profile of four persimon (Diospyros kaki L.) genotypes amplified using 7 primer combinations (P11-M48; P11M49; P11-M50; P11-M51; P11-M53; P11-M55; P11-M58). On the right the standard size marker 50 - 700 bp.

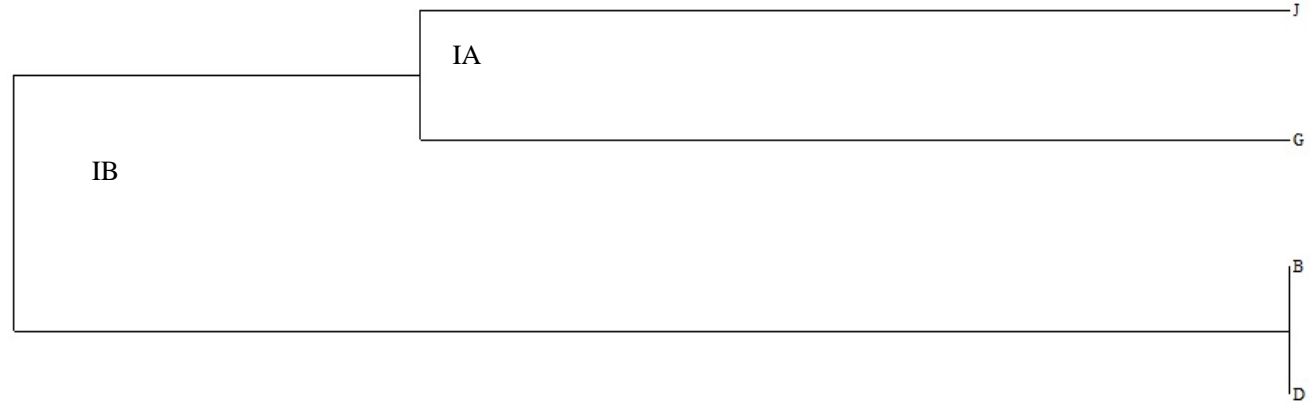

Similarity Coefficient

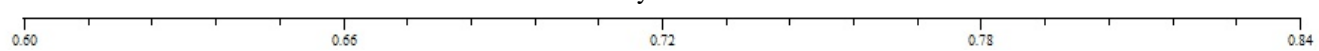

Figure 2. UPGMA cluster analysis of four persimmon samples with seven AFLP primers pairs. 
Genetic relationships between persimmon individuals are grouped based on the value of the similarity coefficient on the dendogram. Persimmon samples formed two groups namely IA and IB. IA group consists of Jrakah and Gebyok accessions that had a similarity coefficient of around 0.675. The IB subclaster shows that Batu accession is genetically very close to Dampit accession with a similarity coefficient of 0.84 . IA and IB groups are clustered at a similarity coefficient around 0.60 .

\section{Conclusion}

The AFLP markers were successfully used to analyze the genetic diversity of four persimmon samples scattered in Central and East Java, Indonesia based on the number of polymorfisms generated by the AFLP markers. Of the seven primers combinations used, the three most suitable ones for the analyzsis of persimmon genetic diversity were P11-M48; P11-M49; and P11-M51. The clustering procedure generated three main branches that clearly separated the genotypes Jrakah (J) and Gebyok (G) and these two from the third group that included the genotypes Batu (B) and Dampit (D), which resulted being very similar to each other at the AFLP markers profile.

\section{Acknowledgement}

Author declare thanks to the University of Sebelas Maret-Indonesia for funding this research from PUT-UNS (PNBP).

\section{References}

Badenes ML and Byrne DH. 2012. Fruit breeding. In Fruit Breeding (Handbook o). https://doi.org/10.1007/978-1-44190763-9

Baswarsiati N, Suhardi N and Rahmawati D. 2006. Potential and Development Area Persimmon Junggo. Buletin Plasma Nutfah, 12(2): 56.

Bruno L. 2000. Simplified AFLP Protocol: Replacement of Primer Labeling by the Incorporation of $\alpha$-Labeled Nucleotides during PCR. BioTechniques, 28(4): 622-623.

Butt MS, Sultan T, Aziz M, Naz A, Ahmed W, Kumar N, Imran M. 2015. Persimmon (Diospyros kaki) Fruit: Hidden Phytochemicals and Health Claims. EXCLI Journal, 14: 542-561.

Das M, Banerjee S, Topdar N, Kundu A, Sarkar D, Sinha MK, Gupta PK. 2011. Development of large-scale AFLP markers in jute. Journal of Plant Biochemistry and Biotechnology, 20(2): 270-275.

Delfianti MNI, Yuniastuti E and Cahyani VR. 2019. Propagation and growth of persimmon (Diospyros kaki L.) in Indonesia. IOP Conference Series: Earth and Environmental Science, 250(1): 15 .

Drahansky M, Paridah M, Moradbak A, Mohamed A, Owolabi F, abdulwahab taiwo, Asniza M and Abdul Khalid SH. 2016. Genetic Diversity and Breeding of Persimmon. In Intech: Vol. i (2nd ed., p. 13).

Du XY, Zhang QL, and Luo ZR. 2009. Comparison of four molecular markers for genetic analysis in Diospyros L. (Ebenaceae). Plant Systematics and Evolution, 281(1-2): 171181.
Guan C, Chen W, Mo R, Du X, Zhang Q and Luo Z. 2016. Isolation and characterization of DkPK genes associated with natural deastringency in C-PCNA Persimmon. Frontiers in Plant Science, 7: 1-11.

Hanafiah DS, Sangita S and Lubis K. 2018. The phenotypic appearance of Japanese persimmon (Diospyros kaki L.f.) in Karo district, North Sumatra, Indonesia. Biodiversitas, 19(2): 509-514.

Hess CM, Wang Z and Edwards SV. 2007. Evolutionary genetics of Carpodacus mexicanus, a recently colonized host of a bacterial pathogen, Mycoplasma gallisepticum. Genetica, 129(2): 217-225.

Ikegami A, Akagi T, Potter D, Yamada M, Sato A, Yonemori K, Inoue K. 2009. Molecular identi W cation of 1-Cys peroxiredoxin and anthocyanidin / X avonol 3 -O- galactosyltransferase from proanthocyanidin-rich young fruits of persimmon ( Diospyros kaki Thunb .). Planta, 230: 841-855.

Jing Z, Ruan X, Wang R and Yang Y. 2013. Genetic diversity and relationships between and within persimmon (Diospyros L.) wild species and cultivated varieties by SRAP markers. Plant Systematics and Evolution, 299(8): 1485-1492.

Jones CJ, Edwards KJ, Castaglione S, Winfield MO, Sala F. 1997. Reproducibility testing of RAPD, AFLP and SSR markers in plants by a network of European laboratories. Molecular Breeding, (3): 381-390.

Kanzaki S, Yonemori K, Sato A, Yamada M, and Sugiura A. 2000. Analysis of the Genetic Relationship Among PollinationConstant and Non-Astringent (PCNA) Cultivars of Persimmon (Diospyros kaki Thunb.) from Japan and China Using Amplified Fragment Length Polymorphism (AFLP). J. Japan. Soc. Hort. Sci., 69(6): 665-670. https://doi.org/10.2503/jjshs.69.665

Kanzaki S, Yamada M, Sato A, Mitani N, Ustunomiya N and Yonemori K. 2009. Conversion of RFLP markers for the selection of pollination-constant and non-astringent type persimmons (Diospyros kaki Thunb.) into PCR-based markers. Journal of the Japanese Society for Horticultural Science, 78(1): 68-73.

Kim CS, Lee CH, Shin J S, Chung YS and Hyung NI. 1997. A simple and rapid method for isolation of high quality genomic DNA from fruit trees and conifers using PVP. Nucleic Acids Research, 25(5): 1085-1086.

Loh JP, Kiew R, Hay A, Kee A, Gan LH and Gan YY. 2000. Intergeneric and interspecific relationships Araceae tribe Caladieae and development of molecular markers using amplified fragment length polymorphism (AFLP). Annals of Botany, 85(3): 371-378.

Makful, Purnomo SS. 2010. Analysis of Genetic Diversity of Mangosteen Based on the Amplified Fragment Length Polymorphism (AFLP) Technique. Jurnal Hortikultura, 20(4): 313-320.

Mba C and Tohme J. 2005. Use of AFLP markers in surveys of plant diversity. Methods in Enzymology, 395: 177-201.

Min T, Yin Xue-ren, Shi Yan-na, Luo Zheng-rong, Yao Yuncong, Grierson D, Ferguson IB and Chen K. 2012. Ethyleneresponsive transcription factors interact in with In Posidonia oceanica cadmium induces changes DNA promoters of ADH and PDC patterning involved in persimmon methylation and ( Diospyros kaki ) fruit de-astringency. Journal of Experimental Botany, 63(18): 6393-6405.

Muluvi GM, Sprent JI, Soranzo N, Provan J, Odee D, Folkard G, McNicol JW, Powell W. 1999. Amplified fragment length polymorphism (AFLP) analysis of genetic variation in Mornga oleifera Lam. Moleculer Ecology, 8: 463-470. 
Mustafa H, Rachmawati I and Udin Y. 2016. Genomic DNA Concentration and Purity Measurement of Anopheles barbirostris. Jurnal Vektor Penyakit, 10(1): 7-10.

Naval MM, Zuriaga E and Badenes ML. 2013. AFLP analysis of mutations induced by gamma irradiation in "rojo brillante" persimmon. Acta Horticulturae, 996: 117-122.

Parfitt DE, Yonemori K, Honsho C, Nozaka M, Kanzaki S, Sato A and Yamada M. 2015. Relationships among Asian persimmon cultivars, astringent and non-astringent types. Tree Genetics \& Genomes, 51(2): 1-9.

Qi X and Lindhout P. 1997. Development of AFLP markers in barley. Molecular and General Genetics, 254(3): 330-336.

Quagliaro G, Vischi M, Tyrka M and Olivieri M. 2001. Identification of Wild and Cultivated Sunflower for Breeding Purposes by AFLP Markers. Journal of Heredity, 92(1): 38-42.

Ridwan H and Ishaq I. 2005. Kajian Sistem Usaha Tani Buah Kesemek (Diosphyros kaki L.f) dan Permasalahannya Di Kabupaten Garut-Jawa Barat. Jurnal Pengkajian Dan Pengembangan Teknologi Pertanian, 8(1): 94-110.

Rohlf F. 1988. NTSYS-pc - Numerical Taxonomy and Multivariate Analysis System. Applied Biostatistics Inc. New York. 2.1.

Sambrook J, Fritsch EF and Maniatis T. 1989. Moleculer Cloning: A Laboratory Manual. Cold Spring Harbor Laboratory Press. New York.

Saunders Ja, Mischke S and Hemeida AA. 2001. The use of AFLP techniques for DNA fingerprinting in plants. Beckman Coulter Application Notes A1910A, 1-9. Retrieved from http://citeseerx.ist.psu.edu/viewdoc/download?doi=10.1.1.134.699 \&amp;rep=rep1\&amp;type=pdf

Setiawan E. 2017. Effecttiveness of IAA, IBA, NAA, and Root-up Application on Persimmon Seedling. Jurnal Hortikultura Indonesia, 8(2): 97-103.

Sundari. 2018. DNA Isolation Technique of Clove Plant Genomes Using Buffer CTAB Modification. Jurnal Biologi Edukasi, 10(2): 21-26.
Suparningtyas JF, Pramudyawardhani OD, Purwoko D and Tajuddin T. 2018. Phylogenetic Analysis of Rubber Tree Clones using AFLP (Amplified Fragment Length Polymorphism) Marker Juniza. Jurnal Bioteknologi \& Biosains Indonesia (JBBI), 5(1): 819.

Suryati E, Puspaningtyas L and Widyastuti U. 2013. Genetic Characteriztics Kappapycus alvarezii Healthy and Infected Disease Ice-Ice by Amplified Fragment Length Polymorphism Methods (AFLP). J.Ris.Akuakultur, 8(1): 21-30.

Syam R, Sadimantara GR and Muzuni. 2012. Genetic Variation Analysis of Cashew Trees (Anacardium accidentale L.). Penelitian Agronomi, 1(2): 164-173.

Vos P, Hogers R, Bleeker M, Reijans M, Lee T. Van De, Hornes M, Zabeau M. 1995. AFLP: A new technique for DNA fingerprinting. Nucleic Acids Research, 23(21): 4407-4414.

Wardani NC, Yuniastuti E and Sulandjari. 2019a. Genetic identification and micropropagation of distributed persimmons (Diospyros kaki) in Indonesia. Pertanika Journal of Tropical Agricultural Science, 42(4): 1343-1359.

Wardani NC, Yuniastuti E and Sulandjari. 2019b. Micropropagation protocol of juvenile buds derived from mature persimmon (Diospyros kaki L.) tree. AIP Conference Proceedings, 2120(July).

Weising K, Nybom H, Wolff $\mathrm{K}$ and Kahl G. 2005. DNA Fingerprinting in Plants (Principles, Methods, and Applications). In M. Hollingsworth (Ed.), Annals of Botany (Second edi, Vol. 97).

Witkowski JA. 199). Biological Laboratory: Cold Spring Harbor Laboratory. Molecular Medicine (Cambridge, Mass.), 1(7): 715717.

Yamagishi M, Matsumoto S, Nakatsuka A and Itamura H. 2005. Identification of persimmon (Diospyros kaki) cultivars and phenetic relationships between Diospyros species by more effective RAPD analysis. Scientia Horticulturae, 105(2): 283290. 